American J. of Engineering and Applied Sciences 3 (3): 521-528, 2010

ISSN 1941-7020

(C) 2010 Science Publications

\title{
Natural Ventilation of Indoor Air Temperature: A Case Study of the Traditional Malay House in Penang
}

\author{
Ahmad Sanusi Hassan and Mahyuddin Ramli \\ School of Housing, Building and Planning, University Sains Malaysia, 11800 Penang, Malaysia
}

\begin{abstract}
Problem statement: It was the aim of the study to analyze the level of performance of natural air ventilation with a case study of the traditional Malay house in Penang, Malaysia. This study provided information on the architectural design in relation to natural air ventilation. It promoted passive design in contrast to most housing design which has poor natural air ventilation because the design was orientated to energy consumption that slightly more than one third of the electric energy was used for heating, ventilating and air conditioning systems. Approach: This analysis used quantitative method which measured temperature, humidity and wind speed of the traditional house. The result indicated the level of performance of cross air ventilation and stack effect. Results: The analysis showed that the traditional house has a design integrated with natural air ventilation system. The indoor house temperature and relative humidity had slightly lower than its outdoor area. However, the indoor area had lower wind speed level than the outdoor area. Conclusion: The study showed that maximum openings on the building walls created high air intakes outside the house to give poor performance of stack effect. The design had more emphasis to cross air ventilation.
\end{abstract}

Key words: Cross air ventilation, stack effect, temperature, relative humidity, wind speed

\section{INTRODUCTION}

This study discusses an influence of natural air ventilation to the design of the traditional Malay house form in Penang, Malaysia. The objective of this study is to illustrate that the traditional Malay house has a focus on natural air ventilation (passive design). Today, the reliance on natural air ventilation gains less attention by the architects who prefer to use mechanical cooling (air-condition) system as main factors to provide thermal comfort. Today, energy crisis becomes an important global issue. Poor passive thermal design in building construction causes the issue become more critical. Almost $68 \%$ of the energy is used for Heating, Ventilating and Air Conditioning Systems (HVACs) (Omer, 2008). It leads to the problem of inefficient use of energy.

The definition of passive design by Commonwealth of Australia (Reardon, 2008) is the building design which does not adopt mechanical cooling or heating but it integrates the natural resources such as winds, sunlight and sun path to gain thermal comfort. The emphasis on the passive design gains its global awareness especially after the Rio Summit in 1992, the conference, which initiates primary global agenda on sustainable development. The aim of this study is to elicit an argument that natural air ventilation is an important factor in a construction of the traditional Malay houses in Penang, Malaysia. This application is not new in traditional architecture. It has been used for generations by the traditional master builders. Reference to the natural surrounding environment becomes the primary indicator. Its significance is presently being reemphasized with scientific approach in building design (Yeang, 2006).

\section{MATERIALS AND METHODS}

Definition of natural air ventilation: The basic principle of passive design is to acquire sustainable use of natural inputs from surrounding environment. This means that this passive design approach applies only from available surrounding resources, which are sunlight, wind and air flow to gain thermal comfort level to the indoor temperature. Thermal comfort achieves when the occupants do not feel that temperature is neither too warm nor too cold. Nishi (1981) defines this term as 'an expression of satisfaction' to the thermal environment. This design does not require mechanical cooling system to achieve comfort and it provides healthy indoor air temperature. It is the aim of this study to understand

Corresponding Author: Ahmad Sanusi Hassan, School of Housing, Building and Planning, University Sains Malaysia, 11800 Penang, Malaysia 
the influence of natural air ventilation in the traditional house design in warm and humid climate. This study analyses the design with natural air ventilation into two categories as follows.

Cross air ventilation: Cross air ventilation is one of the important factors in passive design. It is an alternative solution in the architectural design to reduce the use of mechanical ventilating and cooling system which recorded at present time, consume one third of the total energy consumption (Stavrakakis et al., 2009). Cross air ventilation is an approach used in the traditional house design to gain excellent indoor air quality and temperature applying the maximum ground floor window and door openings which envelope the building wall. Schmidt et al. (1999) argued that it is the most common way to obtain natural air supply in the buildings. This fresh air ventilation is free of pollutants. Poor air ventilation can cause irritation, discomfort or ill health to the occupants (Carslaw, 2007). The excellent cross air ventilation is achieved if the building has large openings on both the windward and leeward sides, and large wall openings with wind direction perpendicular to the openings (Brown and Deekay, 2001). It works when facing the wind direction, creating high pressure at the inlet zone and low pressure at outlet zone (Melaragno, 1982; Stavrakakis et al., 2009).

Optimum indoor air quality may be defined as air which is free of pollutants and has good thermal levels that prevent irritation, discomfort or ill health to the building occupants (Carslaw, 2007). The purpose is to provide comfortable indoor and healthy environment (Curwell and March, 2002). The primary natural aspects of cross air ventilation are air and its temperature. The goal is to achieve the same indoor air temperature and quality as those at the surrounding outdoor air environment. Cross ventilation will create the flow of fresh air crossing through the building. This natural ventilating system however relies on natural forces in order to drive its system. This system relies on two factors: Wind availability and wind direction (Brown and Deekay, 2001; Hamdi et al., 1999). The building design should be integrated and orientated to these factors to gain excellent cross air ventilation. If not, these factors become somewhat unreliable natural resources to achieve excellent air flow and thermal comfort. Chiras (2002) argued that the prevailing wind creates a high pressure zone in contrast to the pressure of interior zone in the building, as a result; it creates cross air ventilation to a low pressure zone, which circulates the outside air throughout the building. The air pressure is high near the centre of the windward wall diminishing to the edges as the wind finds other ways to move across the building (Brown and Deekay, 2001). The air intakes thus are preferable near the centre of the building (the high pressure zones). This cross ventilation directs natural cool winds/breezes into the building, which replaces the polluted warm air and humidity generated by the occupants, sun's heat and radiation from the building materials.

Stack effect: According to Binggeli (2003), stack effect is an air ventilating system which occurs when warm air escapes through roof window openings. The warm air inside the building rises and exits through these roof window openings while cool air infiltrates through the ground window and door openings. The warm air is lighter than the cool air; as a result, this effect causes air pressure. The process creates an upward air movement. Air in the building has a buoyant force because it is warmer and therefore less dense than outside air. The buoyant force causes warm air to rise.

The absence of warm air is replaced by outdoor cool air through the window and door openings at the ground floor. This phenomenon is known as stack effect, stack action or chimney effect. Stack effect works best when the air intakes are as low as possible and the height of building spaces is as great as possible like multiple volume space design to induce stack effect (Klote, 1991). It creates excellent air pressure which causes upward and outward air flow.

The survey: The scope of this study is to measure the performance of natural air ventilation of the traditional house in Penang Island, Malaysia. The survey is conducted in the month of July and August in 2008. The reason is that the average minimum and maximum monthly temperature in July ( $\min 23.4$ and $\max 31.0$ ) and August (min 23.4 and $\max 30.9$ ), and the average monthly rainfall in July $(192 \mathrm{~mm})$ and August (242 $\mathrm{mm})$ are almost the same as the average annual minimum (23.5) and maximum (31.2) temperature, and average annual rainfall $(201 \mathrm{~mm})$ (Malaysia Meteorological Department 2008). There are 4 surveys conducted from $6.00 \mathrm{am}-6.00 \mathrm{pm}$, two in July and the other two in August during the weekends (Saturday or Sunday). The survey is only conducted during overcast sky (partly cloudy) condition, which is a normal type of the sky condition in Malaysia. No survey is done in raining and clear sky condition. The region is predominantly cloudy. Most commonly the cloud pattern is cumulus. The Peninsula is cloudiest in October and November while it has the clearest skies in February (Dobby, 1973). According to Ooi (1963) Penang only receives an average 10 days of blue sky in a year. The limitation of the survey is that it does not focus to analyses monsoon, local and prevailing winds, 
and no survey is conducted at night time from $7.00 \mathrm{pm}-$ $5.00 \mathrm{am}$. There are two types of the measurement taken in the quantitative survey which are cross air ventilation and stack effect. The scale of the measurement can be identified by the temperature level, humidity and wind speed, which can show the performance of cross air ventilation and stack effect. The measurable scale for temperature is in Celsius, humidity in percentage and wind speed in $\mathrm{m} \mathrm{sec}^{-1}$. The device used to record the scale of measurements is anemometer.

The measurable scale of the temperature refers to The Canadian index, called Humidex (Ooi, 1963). This index categorizes human comfort level which is to 'reflect perceived temperature' using combination of temperature and humidity. There is so far no study conducted to give a specific measurable scale of the temperature in the tropical region. The measurable scale also refers to the study of Abdul Rahman (1995). The reason is that perception by the people who live in tropical regions are different from those in temperate and cold regions (Wang and Wong, 2007; Singh et al., 2009). Abdul Rahman (1995) in his study found that the most comfortable indoor temperature in Malaysia (tropical region) ranges from $25.5-28^{\circ} \mathrm{C}$ compared to the general recommendation by World Health Organization (1990), from $18-28^{\circ} \mathrm{C}$. The reason is hot and humid temperature throughout a year gives an impact to the people's perception (Feriadi and Nyuk, 2004) to the thermal comfort at higher temperature in contrast to those in temperate region. Scale No.2 (Table 1) is considered as the best level of performance of the temperature factor. The measurable scale is as shown in Table 1.

Humidity is derived from the word 'humid' which refers to the water vapor content in the air. The scale of measurement is in percentage ranging from $0-100 \%$ relative to the amount of water vapor in the air. Relative humidity shows the level of humidity whether it is dry or humid in particular to indoor environment. The recommended level of indoor humidity (Table 2 ) is in the range of 30-60\% (Wolkoff and Kjaergaard, 2007). The scale of measurement used in this survey is divided to 3 levels of performance which are as follows.

Table 1: The scale of measurement for temperature

\begin{tabular}{lll}
\hline Scale & Description & Celsius \\
\hline 0 & Cold & Less than 16 \\
1 & Cool & $16-25.5$ \\
2 & Comfort & $25.5-28$ \\
3 & Warm & $28-32$ \\
4 & Hot & $32-40$ \\
5 & Extremely hot & Above 40 \\
\hline
\end{tabular}

Table 2: The scale of measurement for relative humidity

\begin{tabular}{lll}
\hline Scale & Description & Celsius $(\%)$ \\
\hline 1 & Low & below 30 \\
2 & Ideal comfort & $30-60$ \\
3 & High & Above 60 \\
\hline
\end{tabular}

The meaning of wind speed is the speed of the air movement. In this survey, the scale of measurement is in meter per second $\left(\mathrm{m} \mathrm{sec}^{-1}\right)$. Beaufort scale No.2 and 3 (Table 3) is considered as the best level of performance of the wind speed factor at $1.6-5.4 \mathrm{~m} \mathrm{sec}^{-1}$. Beaufort scale is used to identify the levels of performance of the wind speed which are as shown in Table 3 (Wolkoff and Kjaergaard, 2007; Wikipedia, 2010).

Seven locations, as indicated in Fig. 1, are selected for the measurements. Location No.1 is for measurement of outdoor area $10 \mathrm{~m}$ from the wall of the core house. This outdoor scale measurement becomes the comparative scale of measurement in order to identify the level of performance in the indoor natural air ventilation. No.2 is measurement of anjung (outdoor porch) area, which has no wall and only covered with roof. The rests are the measurement in indoor areas which are; No.3 is for measurement at the central location of the house; No.4 is for measurement at the north window, No.5 at the west window, No.6 at the south window and No.7 at the east window. By having measurements of the temperature, humidity and wind speed at all these locations, the result will help the research to identify the level of performance of cross air ventilation and stack effect of the traditional houses in Penang.

Table 3: The scale of measurement for wind speed

\begin{tabular}{|c|c|c|c|}
\hline Scale & Description & $\mathrm{m} \mathrm{sec}^{-1}$ & Condition \\
\hline 0 & Calm & $<0.3$ & Calm smoke rises vertically. \\
\hline 1 & Light air & $0.3-1.5$ & Wind motion visible in smoke. \\
\hline 2 & Light breeze & $1.6-3.4$ & $\begin{array}{l}\text { Wind felt on exposed skin. } \\
\text { Leaves rustle. }\end{array}$ \\
\hline 3 & Gentle breeze & $3.4-5.4$ & $\begin{array}{l}\text { Leaves and smaller twigs in } \\
\text { constant motion. }\end{array}$ \\
\hline 4 & Moderate breeze & $5.5-7.9$ & $\begin{array}{l}\text { Dust and loose paper raised. } \\
\text { Small branches begin to move. }\end{array}$ \\
\hline 5 & Fresh breeze & $8.0-10.7$ & $\begin{array}{l}\text { Branches of a moderate size } \\
\text { move. Small trees begin to sway. }\end{array}$ \\
\hline
\end{tabular}

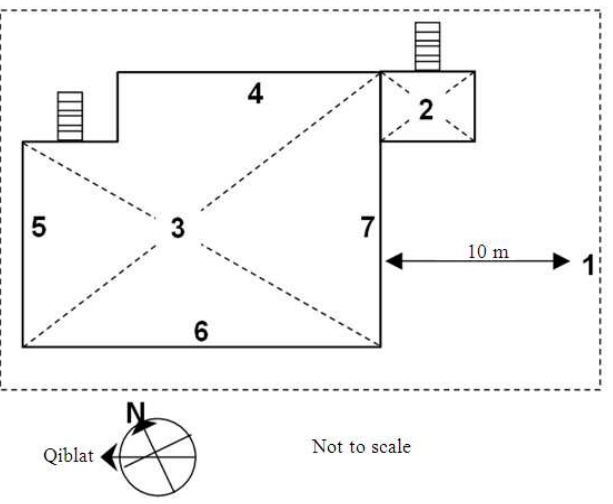

Fig. 1: The schematic house plan shows the selected seven locations of the traditional house in Penang for the quantitative survey 


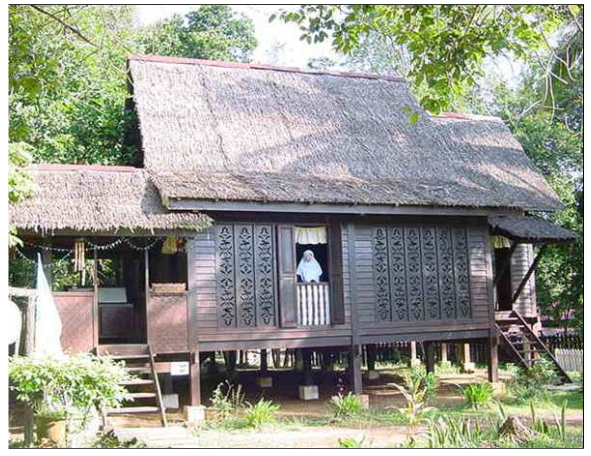

Fig. 2: Traditional Penang Malay house with Rumah ibu (middle), anjung (left) and gajah menyusu (right) additions

The case study: One of the traditional Malay houses in Penang is selected for the case study. This house is located in Balik Pulau district, Penang Island. Bumbung Panjang Berserambi (Long Roof with aisle/veranda) (Nasir and Wan Teh, 1996; Gibbs et al., 1987) traditional house type is the most common and popular roof form built in Penang. Bumbung Panjang Berserambi is characterized by upper and lower parts of long roof form which is constructed with two different slopes of the roof form. It's simple construction accounts for its popularity and is also one of the most highly developed house types in Malaysia. It has a system which allows easy and systematic extensions of gajah menyusu (baby elephant feeding to its mother), and anjung (raised porch) house additions.

There are three distinctive spatial divisions that one can normally find in Penang traditional houses which are rumah ibu (core house) with serambi samanaik (aisle/veranda built parallel to its core house), gajah menyusu addition and anjung addition (Nizam, 2009). Rumah ibu is the central core part of the house which consists of central 'core house' stood on 12 columns placed in regular arrangement and serambi samanaik placed on three columns to form square shaped house form. Serambi samanaik is attached to the core house and its floor level is leveled at the same height to the floor level of the core house, as a result; this creates a larger living area (Fig. 2). It is typical for the traditional houses with a house layout orientated to the qiblat direction. The qiblat direction in Malaysia is at 292 31'16” (Nizam, 2009).

Bumbung Panjang (long roof) is the most common and popular compared to other types of the traditional roof forms. It has simple upper long roof and lower serambi (aisle/veranda) roof. Upper and lower roof parts have two different roof slopes. The upper pitch roof is relatively steep about $45-55 \%$ compared to the lower pitch roof, which has about 25-35\% slope (Hassan, 2001). These two types of roof pitches are erected to form two different roof slopes under one roofing system. This type of roofing system is the most commonly used to construct for the core house (rumah ibu). The floor area built below the upper pitch roof represents the main area of the core house whereas the lower pitch roof is erected at both sides to for aisle/veranda (serambi) floor areas. The most common roofing material used for the bumbung panjang is the attap. Attap is thatch made from nipah (palm type leaves), one type of palm tree species found in the mangrove swamp areas (Nasir and Wan Teh, 1996).

\section{RESULTS}

In this part, it discusses the results of the survey in 3 categories which are the indoor and outdoor performances of temperature, relative humidity and wind speed levels. The results are as follows:

Temperature: The result (Table 4, Fig. 3 and 4) shows that:

- There are very small variations between indoor and outdoor temperature

- Both indoor and outdoor temperatures are dictated by the direction of sunpath

- Most indoor and outdoor temperatures have more than $28^{\circ} \mathrm{C}$ which is not under the ranges of ideal 'comfort level'. The temperatures have only under the ranges of comfort level $\left(25.5-28^{\circ} \mathrm{C}\right)$ from 6.00-9-9.00 am

- The temperature barely reaches to $25.5^{\circ} \mathrm{C}$. The lowest temperature is $27.3^{\circ} \mathrm{C}$ at 6.00 am

- Most indoor and outdoor temperatures have above $32^{\circ} \mathrm{C}$ and the highest average indoor temperature (No.3-7) recorded in the survey is $34.3^{\circ} \mathrm{C}$ at 3.00 $\mathrm{pm}$. These temperatures are slightly under discomfort indoor temperature level which occurs mostly from $12.00-4.00 \mathrm{pm}$

- The time at $2.00 \mathrm{pm}\left(33.4^{\circ} \mathrm{C}\right)$ and $3.00 \mathrm{pm}$ $\left(34.3^{\circ} \mathrm{C}\right)$ have the most discomfort indoor (No.3-7) temperature level

- The indoor temperature (No.3-7) is not under discomfort level but it is not under comfort level (transition level between comfort and discomfort level) at 10.00 am and from 5.00-6.00 pm

- The average indoor temperature (No.3-7) has slightly lower $\left(0.2-0.7^{\circ} \mathrm{C}\right.$ differences) than the outdoor temperature from $9.00 \mathrm{am}-2.00 \mathrm{pm}$

- The average indoor (No.3-7) temperature has slightly higher $\left(0.2-2.7^{\circ} \mathrm{C}\right.$ differences $)$ than the outdoor temperature from 6.00-9.00 am and from 3.00-6.00 pm 
Am. J. Engg. \& Applied Sci., 3 (3): 521-528, 2010

Table 4: Indoor and outdoor performances of the temperature in Celsius

\begin{tabular}{lllllllll} 
Time & 1 (Outdoor) & 2 (Outdoor) & 3 (Indoor) & 4 (Indoor) & 5 (Indoor) & 6 (Indoor) & 7 (Indoor) & Average (Indoor) \\
\hline $6 \mathrm{am}$ & 27.3 & 27.3 & 27.3 & 27.6 & 27.6 & 27.6 & 27.6 & 27.5 \\
$7 \mathrm{am}$ & 28.1 & 28.1 & 28.2 & 28.4 & 28.4 & 28.4 & 28.4 & 28.4 \\
$8 \mathrm{am}$ & 27.6 & 27.6 & 28.1 & 28.3 & 28.3 & 28.5 & 28.6 & 28.4 \\
$9 \mathrm{am}$ & 31.8 & 32.2 & 31.9 & 31.6 & 31.6 & 30.6 & 30.7 & 31.3 \\
$10 \mathrm{am}$ & 31.9 & 33.1 & 32.5 & 32.5 & 32.0 & 31.8 & 31.9 & 32.1 \\
$11 \mathrm{am}$ & 33.4 & 34.6 & 32.0 & 32.4 & 32.5 & 31.6 & 32.2 & 32.1 \\
$12 \mathrm{pm}$ & 33.9 & 35.5 & 34.4 & 34.0 & 33.4 & 33.2 & 32.8 & 33.6 \\
$1 \mathrm{pm}$ & 32.5 & 32.1 & 33.0 & 32.0 & 32.3 & 31.8 & 32.2 & 32.3 \\
$2 \mathrm{pm}$ & 34.5 & 35.7 & 33.7 & 33.8 & 33.3 & 33.3 & 32.8 & 33.4 \\
$3 \mathrm{pm}$ & 31.6 & 34.3 & 33.1 & 33.4 & 34.6 & 35.6 & 34.9 & 34.3 \\
$4 \mathrm{pm}$ & 32.2 & 33.5 & 33.2 & 33.2 & 32.5 & 32.8 & 32.4 & 32.8 \\
$5 \mathrm{pm}$ & 30.8 & 31.0 & 31.5 & 31.7 & 32.3 & 32.4 & 31.7 & 31.9 \\
$6 \mathrm{pm}$ & 29.9 & 30.8 & 29.8 & 29.9 & 31.0 & 29.8 & 30.2 & 30.1 \\
\hline
\end{tabular}

Table 5: Indoor and outdoor performances of the relative humidity

\begin{tabular}{lllllllll}
\hline Time & 1 (Outdoor) & 2 (Outdoor) & 3 (Indoor) & 4 (Indoor) & 5 (Indoor) & 6 (Indoor) & 7 (Indoor) & Average (Indoor) \\
\hline $6 \mathrm{am}$ & 81.7 & 80.2 & 80.2 & 80.0 & 78.0 & 79.0 & 79.0 & 79.2 \\
$7 \mathrm{am}$ & 82.8 & 81.3 & 81.8 & 81.0 & 79.9 & 80.1 & 79.5 & 80.5 \\
$8 \mathrm{am}$ & 86.5 & 85.6 & 83.4 & 83.3 & 83.2 & 82.1 & 81.3 & 82.7 \\
$9 \mathrm{am}$ & 81.5 & 72.6 & 71.6 & 71.4 & 71.0 & 72.7 & 73.6 & 72.1 \\
$10 \mathrm{am}$ & 78.5 & 69.2 & 69.3 & 68.9 & 71.2 & 70.6 & 69.9 & 70.0 \\
$11 \mathrm{am}$ & 67.3 & 63.8 & 69.1 & 67.6 & 68.1 & 69.5 & 69.7 & 68.8 \\
$12 \mathrm{pm}$ & 72.8 & 61.7 & 62.7 & 63.1 & 64.2 & 65.2 & 68.3 & 64.7 \\
$1 \mathrm{pm}$ & 61.6 & 62.0 & 62.5 & 63.5 & 63.6 & 66.4 & 65.0 & 64.2 \\
$2 \mathrm{pm}$ & 65.7 & 57.3 & 62.0 & 61.8 & 62.7 & 64.6 & 66.5 & 63.5 \\
$3 \mathrm{pm}$ & 78.9 & 61.5 & 63.5 & 63.7 & 60.8 & 58.3 & 58.8 & 61.0 \\
$4 \mathrm{pm}$ & 65.8 & 62.4 & 65.0 & 64.0 & 64.7 & 64.6 & 64.5 & 64.6 \\
$5 \mathrm{pm}$ & 79.7 & 69.5 & 69.9 & 69.5 & 66.3 & 67.4 & 67.4 & 68.1 \\
$6 \mathrm{pm}$ & 74.6 & 70.1 & 72.1 & 71.2 & 69.4 & 70.1 & 69.5 & 70.5 \\
\end{tabular}

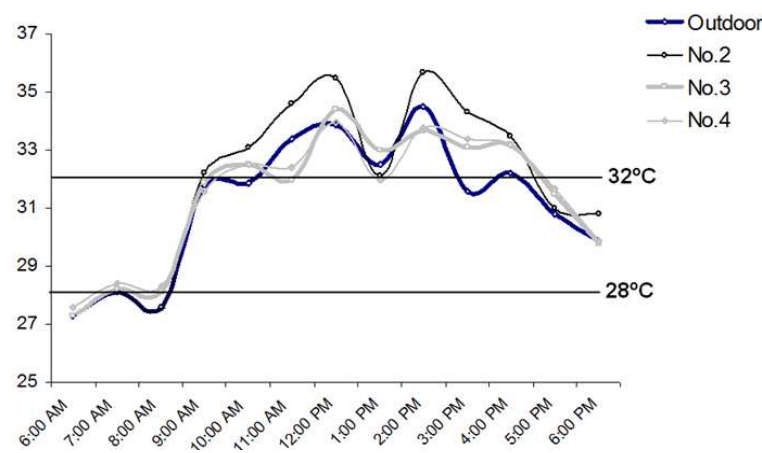

Fig. 3: Indoor and outdoor performances of the temperature for Location No.1 (outdoor), No.2-4

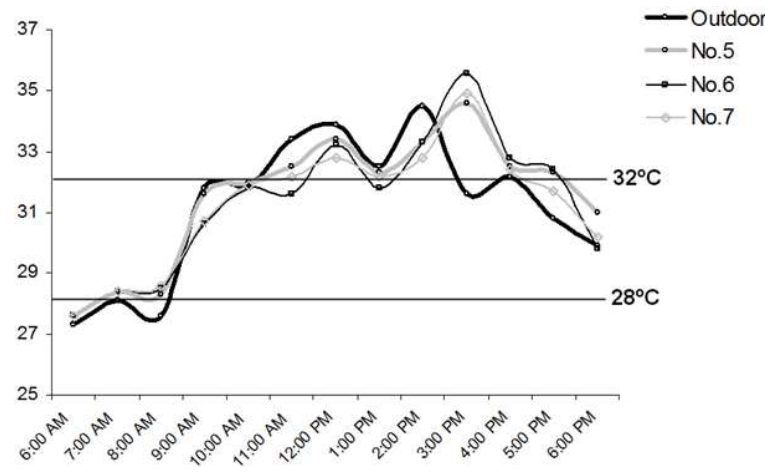

Fig. 4: Indoor and outdoor performances of the temperature for Location No.1 (outdoor), No.5-7

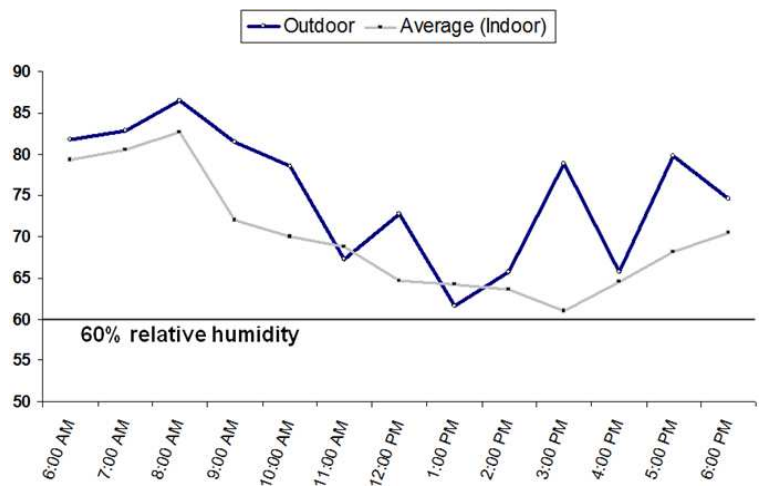

Fig. 5: Indoor and outdoor performances of the relative humidity

Relative humidity: The result (Table 5 and Fig. 5) shows that:

- There is no time indicated that the relative humidity is under ideal 'comfort level' (30-60\%) except at Location No.2 (Outdoor Porch) at 2.00 pm with $57.3 \%$, No.6 at 3.00 pm with $58.3 \%$, and No.7 at $3.00 \mathrm{pm}$ with $58.8 \%$. The other locations have relative humidity levels above $60 \%$

- Both the outdoor and average indoor (No.3-7) relative humidity levels are dictated by the direction of sun path 
Am. J. Engg. \& Applied Sci., 3 (3): 521-528, 2010

Table 6: Indoor and outdoor performances of the wind speed

\begin{tabular}{lllllllll}
\hline Time & 1 (Outdoor) & 2 (Outdoor) & 3 (Indoor) & 4 (Indoor) & 5 (Indoor) & 6 (Indoor) & 7 (Indoor) & Average (Indoor) \\
\hline $6 \mathrm{am}$ & 0.8 & 0.6 & 0.1 & 0.4 & 0.3 & 0.4 & 0.3 & 0.3 \\
$7 \mathrm{am}$ & 1.2 & 1.0 & 0.1 & 0.3 & 0.3 & 0.4 & 0.2 & 0.3 \\
$8 \mathrm{am}$ & 1.4 & 1.1 & 0.1 & 0.2 & 0.3 & 0.3 & 0.3 & 0.2 \\
$9 \mathrm{am}$ & 4.0 & 3.9 & 0.7 & 1.2 & 1.2 & 3.5 & 3.7 & 2.1 \\
$10 \mathrm{am}$ & 8.0 & 3.2 & 0.3 & 1.5 & 1.1 & 1.5 & 3.8 & 1.6 \\
$11 \mathrm{am}$ & 7.2 & 2.6 & 1.8 & 4.0 & 3.5 & 3.9 & 3.9 & 3.4 \\
$12 \mathrm{pm}$ & 5.0 & 2.5 & 1.5 & 2.9 & 3.5 & 3.2 & 2.4 & 2.7 \\
$1 \mathrm{pm}$ & 2.0 & 3.5 & 2.0 & 3.9 & 3.5 & 3.2 & 2.5 & 3.0 \\
$2 \mathrm{pm}$ & 6.8 & 1.5 & 0.7 & 0.7 & 1.4 & 3.9 & 1.5 & 1.6 \\
$3 \mathrm{pm}$ & 4.7 & 3.9 & 0.7 & 1.8 & 1.0 & 3.8 & 1.4 & 1.7 \\
$4 \mathrm{pm}$ & 5.7 & 2.4 & 1.0 & 2.7 & 6.5 & 1.7 & 1.4 & 2.7 \\
$5 \mathrm{pm}$ & 7.8 & 5.0 & 2.0 & 3.2 & 2.8 & 3.5 & 2.9 & 2.9 \\
$6 \mathrm{pm}$ & 8.4 & 7.2 & 2.5 & 3.5 & 3.2 & 3.7 & 3.5 & 3.3 \\
\hline
\end{tabular}

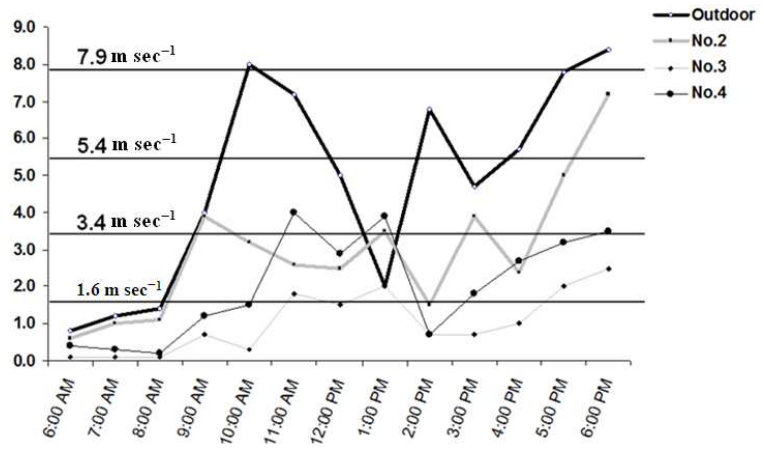

Fig. 6: Indoor and outdoor performances of the wind speed for Location No.1 (outdoor), No.2-4

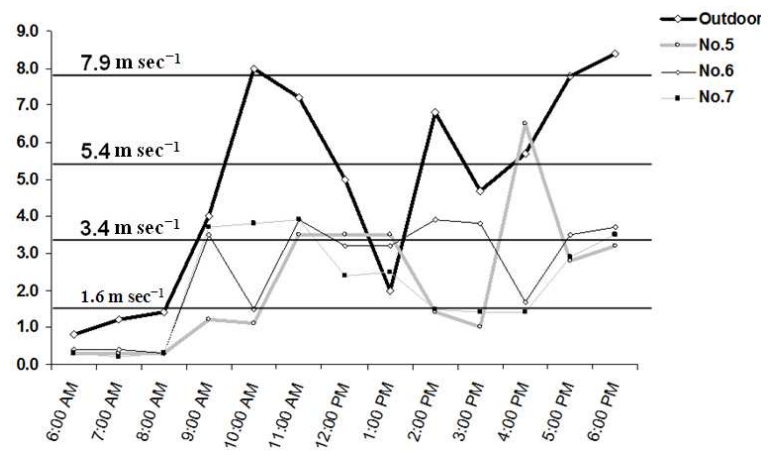

Fig. 7: Indoor and outdoor performances of the temperature level for Location No.1 (outdoor), No.5-7

- All the average indoor (No.3-7) relative humidity levels from $6.00 \mathrm{am}-6.00 \mathrm{pm}$ are lower than the outdoor relative humidity levels except at $11.00 \mathrm{am}$ and $1.00 \mathrm{pm}$. The differences between the outdoor and average indoor (No.3-7) relative humidity level are $17.9 \%$ (highest) and $1.2 \%$ (lowest)

- The lowest average indoor (No.3-7) relative humidity level is $61 \%$ and the highest level is $82.7 \%$ whereas the lowest outdoor relative humidity level is $61.6 \%$ and the highest level is $86.5 \%$
- The average indoor (No.3-7) relative humidity levels are high from 6.00-10.00 am ranged from $70-82.7 \%$, compared to the average level from 11.00 am-6.00 pm ranged from $61-70.5 \%$

- The average indoor (No.3-7) relative humidity levels are below $70 \%$ when the temperature is high (late morning, afternoon and evening) and above $70 \%$ when the temperature is low (early morning and late evening)

Wind speed: The result (Table 6, Fig. 6 and 7) shows that:

- The pattern of wind speed level for the outdoor area is under category of light air $\left(0.3-1.5 \mathrm{~m} \mathrm{sec}^{-1}\right)$ in the early morning, light breeze $\left(1.6-3.4 \mathrm{~m} \mathrm{sec}^{-1}\right)$ and gentle breeze (3.4-5.4 $\mathrm{m}$ ) in late morning and afternoon, and moderate (5.5-7.9 $\left.\mathrm{m} \mathrm{sec}^{-1}\right)$ and fresh breeze (8.0-10.7 m sec$\left.{ }^{-1}\right)$ in the evening

- The outdoor area has higher wind speed level than the average indoor (No.3-7) area except at $1.00 \mathrm{pm}$. The difference varies from $0.5-6.4 \mathrm{~m} \mathrm{sec}^{-1}$

- The pattern of wind speed level for the average indoor area (No.3-7) is under category of calm $\left(<0.3 \mathrm{~m} \mathrm{sec}^{-1}\right)$ in the early morning, light breeze (1.6-3.4 m sec$\left.{ }^{-1}\right)$ in late morning, afternoon and evening

- The average indoor (No.3-7) wind speed levels barely reach $3.4 \mathrm{~m} \mathrm{sec}^{-1}$ under gentle breeze condition which is the ideal wind speed level

- The indoor area (No.3) at the central location (No.3) has the lowest average wind speed level in contrast to the other indoor areas near the window openings

\section{DISCUSSION}

The analysis found that the design of the traditional house with the case study in Penang has good cross air ventilation and stack effect. Both indoor and outdoor 
temperatures as well as the relative humidifies are dictated by the direction of sunpath. The average indoor temperature (No.3-7) has slightly lower $\left(0.2-0.7^{\circ} \mathrm{C}\right)$ than the outdoor temperature from $9.00 \mathrm{am}-2.00 \mathrm{pm}$, and the average indoor (No.3-7) relative humidity levels are lower that the outdoor relative humidity levels which shows better performance for the design of indoor areas under category of temperature and humidity level. Double roof system induces the flow of warm air and humidity through the openings between lower and upper roof known as stack effect. However the study found that in contrast to the outdoor wind speed level, the average indoor (No.3-7) wind speed level barely reach under the category of gentle breeze (3.4-5.4 m sec $\mathrm{m}^{-1}$ ) condition which is the ideal wind speed level. The pattern of wind speed level for the average indoor area is calm $\left(<0.3 \mathrm{~m} \mathrm{sec}^{-1}\right)$ in the early morning, light breeze (1.6-3.4 $\left.\mathrm{m} \mathrm{sec}^{-1}\right)$ in the late morning, afternoon and evening. The study shows that the indoor area gains low induction from stack effect. This is because in contrast to cross air ventilation, stack effect requires the amount of air intakes as low as possible to induce the air pressure to the indoor space. Maximum openings on the building walls create high air intakes outside the house to give poor performance of stack effect. The design has more emphasis to cross air ventilation.

\section{CONCLUSION}

In conclusion, the analysis shows that maximum openings on the building walls create high air intakes outside the house to give poor performance of stack effect. Maximum openings on the building walls create high air intakes outside the house to give poor performance of stack effect. The design in this case study of the traditional Malay house in Penang has more emphasis to cross air ventilation. Similar result of the analysis also can be anticipated to all the other types of the traditional Malay houses in this country if the same study is conducted to these houses because of their similarity in the house design.

\section{ACKNOWLEDGEMENT}

This study is under Research University Grant supported by University Sains Malaysia. The main author is the co-researcher under Prof. Ir. Dr. Mahyuddin Ramli (co-author) as the Project Leader.

\section{REFERENCES}

Abdul Rahman, A.M., 1995. Housing design in relation to environmental comfort. Build. Res. Inform., 23: 49-54.
Binggeli, C., 2003. Building Systems for Interior Designers. 1st Edn., John Wiley and Sons Inc., New Jersey, ISBN: 0-471-41733-5, pp: 452.

Brown, G.Z. and M. Deekay, 2001. Sun, Wind and Light: Architectural Design Strategies. 2nd Edn., John Wiley and Sons Inc., New York, ISBN: 0471-34877-5, pp: 382.

Carslaw, N., 2007. A new detailed chemical model for indoor air pollution. Atmosph. Environ., 41: 1164-1179.

Chiras, D.D., 2002. The Solar House: Passive Heating and Cooling. 1st Edn., Chelsea Green Publishing Company, Vermont, ISBN: 1-931498-12-1, pp: 274.

Curwell, S.R. and C. March, 2002. Hazardous Building Materials: A Guide to the Selection of Environmentally Responsible Alternatives. 2nd Edn., BCF Publishing Ltd., London, ISBN: 0-41923450-0, pp: 196.

Dobby, E.H.G., 1973. Southeast Asia. 11th Edn., University of London Press, London, ISBN: 034009-09-87, pp: 429.

Feriadi, H. and H.W. Nyuk, 2004. Thermal Comfort for Naturally Ventilated Houses in Indonesia. Energy Build., 36: 614-626.

Gibbs, P., Y.A. Rahman and Z. Kassim, 1987. Building a Malay House. Oxford University Press, Singapore, ISBN: 0195888618, pp: 99.

Hamdi, M., G. Lachiver and F. Michaud, 1999. A new predictive thermal sensation index of human response. Energy Build., 29: 167-178.

Hassan, A.S. 2001. Issues in Sustainable Development of Architecture in Malaysia. USM Press, Penang, ISBN: 983-2514-84-3, pp: 125.

Klote, J.H., 1991. A general routine for analysis of stack effect. National Institute of Standards and Technology, Report, United States Department of Commerce, Gaithersburg, pp: 28.

Melaragno, M.G., 1982. Wind in Architectural and Environmental Design. 1st Edn., Van Nostrand Reinhold, New York, ISBN: 0-442-25130-0, pp: 684.

Nasir, A.H. and W.H. Wan Teh, 1996. The Traditional Malay House. 1st Edn., Fajar Bakti Press, Shah Alam, ISBN: 9-676-53341-6, pp: 91.

Nishi, Y., 1981. Measurement of Thermal Balance of Man. In: Bioengineering, Thermal Physiology and Comfort, Cena, K. and J.A. Clark (Eds.)., 1st Edn., Elsevier Scientific Publisher, Amsterdam, pp: 29-39.

Nizam, A., 2009. Technique's Assessing the Qiblat Direction. Qiblat Direction. http://hikmatun.wordpress.com/2007/01/07/arahkiblat/

Omer, A.M., 2008. Renewable building energy systems and passive human comfort solutions. Renew. Sustain. Energy Rev., 12: 1562-1587. 
Ooi, J.B., 1963. Land People and Economy in Malaya. 1st Edn., Longmans, Green and Co. Ltd., London, pp: 426.

World Health Organization, (WHO), 1990. Indoor environment: Health aspects of air quality, thermal environment, light and noise. World Health Organization, Report, London, pp: 1-128. http://whqlibdoc.who.int/hq/1990/WHO_EHE_RU D_90.2.pdf

Reardon, C., 2008. Passive Design. Your Home Technical Manual, 4th Edn., Commonwealth of Australia, Canberra, pp: 69-70. http://www.yourhome. gov.au/technical/fs41.html

Schmidt, D., A. Maas and G. Hauser, 1999. Experimental and theoretical case study on cross ventilation: Designing a mathematical model. Nordic J. Build. Phys., 2: 1-17.

Singh, M.K., S. Mahapatra and S.K. Atreya, 2009. Thermal performance study and evaluation of comfort temperatures in vernacular buildings of North-East India. Build. Environ., 45: 320-329. DOI: 10.1016/j.buildenv.2009.06.009
Stavrakakis, G.M., P.L. Zervas, H. Sarimveis and N.C. Markatos, 2009. Development of a computational tool to quantify architectural-design effects on thermal comfort in naturally ventilated rural houses. Build. Environ., 45: 65-80. DOI: 10.1016/j.buildenv.2009.05.006

Wang, L. and N.H. Wong, 2007. Applying natural ventilation for thermal comfort in residential buildings in Singapore. Architect. Sci. Rev., 50: 224-233.

Wolkoff, P., P. and S.K. Kjaergaard, 2007. The dichotomy of relative humidity on indoor air quality. Environ. Int., 33: 850-857. DOI: 10.1016/J.envint.2007.04.004

Wikipedia, 2010. Beaufort model. http://en.wikipedia.org/wiki/Beaufort_scale

Yeang, K., 2006. Ecodesign: A Manual for Ecological Design. Wiley-Academy, London, ISBN: 9832726-40-9, pp: 499. 